WORKING PAPER - NO. 2020-92

\title{
Informing Entrepreneurs: Public Corporate Disclosure and New Business Formation
}

John M. Barrios, Jung Ho Choi, Yael V. Hochberg, Jinhwan Kim, and Miao Liu JUNE 2020

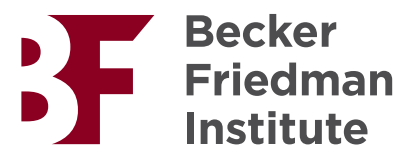




\title{
Informing Entrepreneurs:
}

\section{Public Corporate Disclosure and New Business Formation*}

\author{
John M. Barrios \\ University of Chicago Booth \\ Jung Ho Choi \\ School of Business \\ Stanford University \\ School of Business \\ Jinhwan Kim \\ Stanford University \\ Miao Liu \\ University of Chicago \\ Booth School of Business
}

Yael V. Hochberg

Rice University \& NBER

First Version: June 22, 2020

Current Version: June 22, 2020

\begin{abstract}
We examine the relationship between public firm disclosure and aggregate new business formation. Consistent with the notion that public company disclosures provide information spillovers that reduce the extent of uncertainty about new investment opportunities, we find that increased public firm presence is positively associated with new business formation in an industry. Furthermore, using plausibly exogenous information shocks generated by new IPOs in a geographic area, we find that post-IPO, new business registration in the public company's geographic area rise by 4 to $10 \%$, consistent with soft information channels serving to reinforce hard information in public disclosures. New IPOs are associated with significant increases in Edgar downloading activity in the IPOs' geographic area, consistent with the notion that public firm disclosures are providing important investment opportunity information that facilitates new business formation.
\end{abstract}

JEL Codes: D80, D81, D83, L26, M41

Keywords: Entrepreneurship, Financial Disclosures, Real Effects, Externalities, IPOs.

\footnotetext{
* We thank seminar participants at Columbia University for helpful conversations, comments, and suggestions. Jin Deng, Lingyu $\mathrm{Gu}$, and Charles Zhang provided excellent research assistance. All errors are our own. Barrios gratefully acknowledges the support of the Stigler Center at the University of Chicago Booth School of Business. Corresponding Author: John Barrios (john.barrios@chicagobooth.edu).
} 


\section{INTRODUCTION}

One of the fundamental questions in accounting is whether, and to what extent, financial reporting facilitates the allocation of capital to investment opportunities (Roychowdhury, Shroff, and Verdi, 2019). Much of the early research in this area focused on the role of financial reporting in a setting with agency frictions that arise from information asymmetry. This stream of literature explores whether financial reporting transparency lowers the cost of capital (Healy and Palepu, 2001; Verrecchia, 2001; Beyer et al., 2010) and improves contracting efficiency (Bushman and Smith, 2001; Lambert, 2001; Armstrong et al., 2010). More recently, a stream of literature focuses on learning from public disclosures that arise from the presence of uncertainty about investment opportunities (Roychowdhury et al. 2019). More specifically, this research provides evidence that accounting information (as reported by the firm or disclosed by peer firms) affects managers' information sets, and thereby affects their decisions (Badertscher, Shroff, and White, 2013; Shroff, Verdi, and Yost 2017).

To date, the primary focus of the literature on the public disclosure learning channel has focused on the intensive margin - the investment efficiency of the firm itself. In this paper, we build upon this work and explore how public firm disclosure may affect learning on the extensive margin, in the form of new business formation. Specifically, we consider whether firms' public accounting disclosures provide information that can potentially inform entrepreneurs in their decisions to start a new business in the face of uncertainty about the profitability of the market opportunity.

To launch a successful and sustainable business, entrepreneurs must work to discover profit opportunities. Opportunities may exist on the output side of production, the input side, or both, and the existence of such opportunities may lead to the creation of new firms. Much of this 
entrepreneurial process involves seeking and interpreting information. As a result, gathering information for decision-making is a critical activity for the would-be entrepreneur, playing a first-order role in the decision to found a new firm. Public firms disclose significant amounts of information, such as their business strategy, financial performance, expected future outlook, current, and future investment outlays, material contracts, and business risks. Moreover, information intermediaries that cover public firms - such as financial analysts and the business press-analyze, discuss, and disseminate firms' disclosures. Collectively, these disclosure activities can improve the information environment within the industry vertical and geographical area of publicly-traded firms, reducing uncertainty regarding demand, supply, and cost conditions (Mitchell and Mulherin, 1996; Admati and Peiderer, 2000; Badertscher et al., 2013).

We hypothesize that the information contained in public firm disclosures serves to reduce uncertainty regarding the future returns to entrepreneurial activities. As a result, we expect an increase in entrepreneurial entry when public corporate disclosures are present as an additional information source. This effect should be strongest in geographic proximity to the public firms, as the transmission of soft information serves to augment and add color to the publicly transmitted information in the disclosures, and such transmission likely declines with distance (Liberti and Petersen, 2019).

To examine this hypothesis empirically, we utilize two sources of variation in public firm disclosure: (1) variation at the industry level, as measured by the proportion of public companies in an industry; and (2) geographic variation in public disclosure information, as measured by new IPOs in the local geographic area. To capture new business starts, we employ complementary sources of data: (1) the number of establishment births from the U.S. Census Statistics of U.S. Business, and (2) a novel dataset of the full census of new for-profit business 
registrations in the United States with zip code and county-level information, provided by the Startup Cartography Project (SCP). ${ }^{1}$ Our two data sources provide us with a comprehensive view of new business formation in the U.S., across both industries and geographies.

We begin by exploring the relationship between public firm presence at the industry-year level and establishment births at the countylevel. To measure public firm presence for an industry, we follow Shroff et al. (2017) and Roychowdhury et al. (2019) and use the number of public firms in an industry (3-digit SIC) divided by the total number firms in the industry, both public and private. Using multivariate analysis with year, industry, and county fixed effects, we show that across industries, an increase of one quintile of public firm presence in an industry is associated with a $10 \%$ increase in new establishment births. ${ }^{2}$

To further identify a causal relationship, we turn to a difference-in-differences (D.D.) design and test the extent to which IPOs generate useful information for geographically local entrepreneurs. Specifically, we compare new establishments in county-industries where an IPO has been initiated to those in county-industries without an IPO, before and after the occurrence of the IPO. An IPO represents a significant improvement in the information environment through channels such as direct firm disclosures, local newspaper circulations, and analyst coverage. We expect the information to be most relevant for entrepreneurs since the IPO likely provides useful informationof local economic conditions where they plan to start their own businesses. Relatedly, soft information can also reinforce and expand upon the information disclosed through IPOs via interactions with local agents. Consistent with these arguments, we show that a

\footnotetext{
${ }^{1} \mathrm{http}: / /$ www.startupcartography.com.

${ }^{2}$ In the appendix, we further show that moving from the bottom quintile of public firm presence in an industry to the top quintile is associated with a $12 \%$ increase in the number of establishments with 0 to 5 employees in that industry-year. Consistent with public information being more useful for entrepreneurs in their decision to start the new firm, we find that the relationship between public firm presence and the number of establishments is larger for these small firms than for medium, large or extra-large establishments. We estimate that the relationship between establishment growth and public firm presence is more than $40 \%$ greater for small firms than for larger firms.
} 
new IPO is associated with an increase of 11 to $22 \%$ in new establishment births in its local county compared to that of a non-local county. These effects are more pronounced among local establishments that share the same industry as the IPO firm relative to those that are in different industries. This is consistent with public information spilling over to economically related industry peers and less consistent with local economic shocks driving our results.

While the analysis above is consistent with public firm disclosures encouraging new business establishments, it relies on establishment births, which may be new branches of existing companies, rather than true new firm formation. We address this drawback by using a more refined measure of new business formation: business registrations from the Startup Cartography Project (SCP). While the business registration data from SCP does not provide information on the industry, and therefore cannot be used for industry-level analyses, it does provide comprehensive coverage of new business formation at the geographic level.

Using a similar D.D. design as in our establishment-level tests, we compare new business registrations in counties where an IPO has been initiated to those in counties that have not experienced a recent IPO, before and after the occurrence of the IPO. Our D.D. specification includes a vector of time-varying county characteristics (population income per capita and the number of public firms) as well as county and quarter-year fixed effects. In our strictest specification, we include country-specific linear trends. We find that post-IPO county-quarters observe a 4 to $10 \%$ increase in new business registrations relative to county-quarters in which there were no recent IPOs. This translates into 5-12 new business registrations a quarter, on average, after the IPO.

We proceed to explore whether increases in information from the IPOs lead individuals to consider the possibility of launching a business, even if they do not eventually choose to launch 
one. To do so, we measure entrepreneurial interest (expression of interest in entrepreneurship) using google searches for terms related to entrepreneurship, such as "how to start a business" or "how to incorporate" (Barrios et al., 2020). Consistent with our prior findings, the D.D. specification documents an approximate $16.2 \%$ increase in search share for entrepreneurship and new business formation terms after an IPO.

We then turn to examine the mechanism underlying our hypothesis, conducting three sets of complementary tests that reinforce the notion that the new business formation that we document is driven by entrepreneurs' receipt of information that reduces the uncertainty regarding the profitability of entrepreneurial activity. First, to corroborate the inference that our results are driven by information provision to entrepreneurs, we consider cases when an IPO is likely to provide more information versus less. Specifically, we separate IPOs into spinoffs from public firms versus private-to-public IPOs. This comparison is based on the view that the production of new information is likely more prevalent when a private firm goes public than when a subsidiary is spun off, as the parent was reporting public information on the subsidiary prior to the IPO. Consistent with our hypothesized information mechanism, we see the increase in new firm registrations is concentrated around private-to-public IPOs.

Second, we expect a primary mechanism through which public information facilitates entrepreneurship is through the reduction in local economic uncertainty. This reduction in uncertainty can then be used by the potential entrepreneur to make a more informed decision as to starting a new firm. That is, if the information is the driver underlying our findings, we would expect our results to be concentrated in situations where economic uncertainty is the highest exante. Consistent with these arguments, we find that the positive link between IPO and local 
entrepreneurship is more pronounced in locations where economic uncertainty, measured by volatility of wage growth, is high.

Third, we further validate the information story by examining how Edgar downloads of public firm reporting react around new IPOs, and how these downloads relate to new business registrations. We document that downloads of public firm reports from Edgar in the county of a new IPO firm increase by 23 to $26 \%$. Moreover, we demonstrate that a one standard deviation increase in the number of downloads is linked to a $1.7 \%$ increase, or six additional business registrations, in the county. These tests corroborate the inference that the positive link between IPO and new business registrations are driven by more public disclosures available to potential entrepreneurs. Collectively, the above analyses validate an information-based effect of IPOs on entrepreneurial activity and raise the bar for an alternative channel to explain our results.

Notwithstanding the above mechanism tests, we further explore the plausibility of an important alternative story to our findings. That is, omitted factors such as local economic growth in the area may be jointly determining IPO activity and new business formation. We examine the plausibility of this alternative hypothesis by first testing for the parallel trend's assumption. If our results were driven by growth, we would expect a divergence in pre-IPO trends in business registrations between IPO and non-IPO counties prior to the IPO in event time. ${ }^{3}$ On the other hand, an information effect would only manifest after the IPO as relevant information is revealed after the IPO. We find evidence of parallel trends, which alleviates concerns that spurious patterns in growth are driving our results, and is more consistent with information being revealed through the IPO. Relatedly, we show that average weekly wages do not increase following the IPO, while our entrepreneurial activity measures do, suggesting that

\footnotetext{
${ }^{3}$ We also use city-specific linear trends in our DD specification as controls for pre-IPO event growth patterns in the county explicitly.
} 
the effect we document is unlikely to be purely driven by overall economic growth patterns, which would likely have a positive impact on wages.

This paper makes several contributions to the literature. First, our paper adds to the literature on the externalities from public firm disclosures (Durnev and Mangen, 2009; Beatty, Liao, and Yu, 2013; Badertscher, Shroff, and White, 2013; Shroff, Verdi, and Yu, 2013). For example, Badertscher, Shroff, and White (2013) show that private firms are more responsive to their investment opportunities when they operate in industries with greater public firm presence. Moreover, Durnev and Mangen (2009) show that accounting restatements are associated with lower abnormal returns and reduced investment by non-restating firms in the industry. The authors suggest a "learning" effect in that restatements convey information about investment projects to the managers of restating firms' competitors. While these studies focus on the intensive margin effects of disclosure spillovers, we contribute to this literature by using IPOs and the broader entrepreneurial setting of new business formation to show the positive externalities of public firm disclosures also affect the extensive margin of new business formation. ${ }^{4}$ Our setting and the mechanisms we study allow us to understand further the information spillovers from public firms in generating entrepreneurs and new businesses.

Second, our paper also contributes to the debate on the cost and benefits of disclosure regulation. Despite its pervasiveness, disclosure regulation is often quite challenging to justify because of market-based incentives to disclose information (Admati and Pfleiderer, 2000; Leuz and Wysocki, 2008; Berger, 2011). That is, since the firm ultimately bears the costs of obfuscating information, the firm has incentives to disclose information to reduce such costs

\footnotetext{
${ }^{4}$ Breuer (2018) studies the impact of financial reporting regulation on entry and exit behaviors from a productivity perspective without explicitly differentiating between expansion of existing firms and formation of new firms. We extend and complement this study by explicitly examining the impact of public disclosure on new business formation.
} 
(see, e.g., Admati and Pfleiderer, 2000). One justification put forward in favor of mandatory disclosure is the presence of positive externalities to such disclosure (e.g., Kim and Valentine (2020)). This paper provides additional evidence consistent with the positive externalities of corporate disclosures, namely, spurring new business formation.

Finally, our paper speaks to the literature on entrepreneurship and new business formation. New business formation is a critical driver of economic development (Haltiwanger et al., 2013). Our evidence provides insights into the process through which potential entrepreneurs obtain relevant information when deciding to launch a new venture. Specifically, we find that the presence of public firms and IPOs in an area foster increases in disclosure and an improvement in the information environment. Collectively, these disclosures help to provide a more comprehensive view of the industry and region, thereby reducing uncertainty and facilitating new business formation.

\section{FRAMEWORK: ENTREPRENEURSHIP AND PUBLIC FIRM DISCLOSURE}

Our examination of the role of firms' public disclosure on entrepreneurial activity is based on the view that an individual's decision to enter entrepreneurship versus full-time wageemployment is determined by the relative returns offered by the two choices. Returns confer utility, and agents choose the option that maximizes their expected utility (Lucas, 1978; Kihlstrom and Laffont, 1979; Jovanovic, 1982). We incorporate the notion of information to this decision. Specifically, in our case, whether an individual chooses to launch a new business is the result of two forces, their entrepreneurial ability and the quantity of available information. As previous theoretical work shows, these forces operate through their impact on the ratio of entrepreneurial profits to wages. This ratio can be seen to capture the differential return and the differential on risk-taking on the capital investment, in the case of founding a new firm and on 
the labor income if the individuals stay as full-time employees. Under this view, entrepreneurs are risk-averse. Because the capital markets provide too little capital to entrepreneurs as a result of moral hazard and adverse selection problems (e.g., LeRoy and Singell 1987), entrepreneurs must finance themselves and bear the risk of failure. Thus we can focus on changes in entrepreneurship driven by changes in the quantity of available information.

Our emphasis on information stems from the fact that entrepreneurs look for profits, and profits result from differences between the price of outputs and the costs of inputs. The entrepreneur, thus, looks for maximal price differences between potential bundles of inputs and possible bundles of outputs. Given the vast number of prices of inputs and outputs in an economy, entrepreneurs must do an extensive search on several markets in order to maximize profits because of the scarcity of information. This "discovery process" is formalized in the work of Stigler (1961), amongst others. In the context of information asymmetry, an entrepreneur can discover the opportunity to create a new venture, or he can create that opportunity through an uncertain process (Alvarez \& Barney, 2007; Alvarez, Barney, \& Anderson, 2013). In both circumstances, the entrepreneur must be a price searcher and search for all the managerial information needed in order to create and develop the new venture and maximize profits. It is in this process that information from public disclosures may be useful to the entrepreneur by reducing the search costs via the enrichment of the information environment. Moreover, coverage by information intermediaries combines with the direct information of public firm disclosure to give a more complete perspective of the current economic environment and future outlook for the industry.

In essence, we can think of information as a factor of production in the entrepreneurial production function, thus increases in the price of information significantly and negatively 
affects the entrepreneur's efficiency. In contrast, increases in the quantity of information affect it positively. For example, the additional information reduces the uncertainty of returns of entrepreneur activities and increases the expected returns of starting a new business (Bloom, 2009; David et al., 2016). This reduction in uncertainty can then be used by the potential entrepreneur to make a more informed decision as to starting a new firm.

We can then think of public firm disclosures generating a higher volume of information for entrepreneurs. This new abundance of information, in turn, reduces the cost of information, which raises the firms' potential profit and, therefore, the managerial productivity of all existing and potential entrepreneurs, everything else being constant. This reduction in uncertainty induces additional wage earners with lower ability levels to become entrepreneurs, and thus, the number of entrepreneurs in the economy also rises. Given these arguments, we predict more information from public firm disclosures to lead to increases in entrepreneurial activity and new business formation. We examine this hypothesis empirically in the following sections.

\section{DATA SOURCES AND KEY VARIABLES}

In this section we describe our measures of public firm disclosure as well as our two measures of new business formation, and the various databases used to construct these variables. As an overview, our sample is comprised of 359,892 county-quarter observations. When data is available, we also conduct tests at the county-industry-quarter level comprised of 875,506 county-industry-quarters.

\section{A. Public Firm Measures}

Our analysis utilizes two primary measures of public firm disclosure, which serves as the independent variable of interest.

\section{III.A.1. Public Firm Presence}


Our first proxy for public disclosure is Public Firm Presence, defined as the proportion of public firms in each NAICS 3-digit industry-year, following Badertscher et al. (2013) and Shroff et al. (2017). Data on the total number of firms in each industry is obtained from the Census Bureau, and we proxy for the number of public firms in each industry using data from Compustat. To minimize the influence of outliers, we sort Public Firm Presence into quintiles each year to create the variable Pub Firm Presence Quintile.

\section{III.A.2. Initial Public Offerings}

Our second proxy for public disclosure is Post IPO, defined as a county-specific indicator variable that equals to one for every county-quarters after the IPO quarter, and zero otherwise. Our motivation for this proxy stems from the fact that IPOs represent a significant expansion in public information available to the public through mandated corporate filings, newspaper coverages, and analyst reports, all of which provide relevant information for would-be entrepreneurs. For example, Ryans (2017) shows that the most downloaded corporate filings are the S-1 filings from IPOs- even more so than 10-Ks, 10-Qs, and 8-Ks. This is a testament to the importance of IPO-related disclosures as a source of information to the public, and by extension to potential entrepreneurs.

We include counties that never had an IPO in our sample. These serve as a benchmark comparison group, and have the variable Post IPO set to zero over the entire sample period. We collect IPO issuance data using Thomson Financial's SDC New Issues database. The sample starts from 1988 Q1 and ends in 2016 Q4. The data contains county as well as industry information at the 2-digit SIC level for each IPO, which we exploit in certain model specifications described further below. Following the IPO literature, we exclude IPO filings of financial firms (SIC codes between 6000 and 6999), unit offerings, closed-end funds (including 
REITs), ADRs, limited partnerships, special acquisition vehicles, and spinoffs. We identify 7,892 IPOs over the sample period of 1988 to 2006. In Figure 1, we plot the geographic variation in IPOs among U.S. counties.

\section{B. Business Formation Measures}

We utilize two complementary measures of entrepreneurial activity, which serve as our dependent variable of interest.

\section{III.B.1. Establishment Births}

Our first measure comes from the U.S. Census Statistics of U.S. Business database (SUSB), which covers all U.S. business establishments with paid employees spanning the years 2000 to 2015. The data source provides information on new establishment births at the county level at the 2-digit NAICS level. The SUSB defines an establishment birth as establishments that have zero employment in the first quarter of the initial year and positive employment in the first quarter of the subsequent year. We define $\log (1+$ Establishment Birth $)$ as the natural logarithm of one plus the number of new establishment formations, measured at the county and 2-digit NAICS level.

\section{III.B.2. Business Registrations}

Our second measure of new business formation uses new business registrations. Our business registration data is obtained at the county level from the Startup Cartography Project (SCP) database. The SCP leverages business registration records, which are public records created when an individual register's a new business as a corporation, LLC, or partnership. Importantly, as noted by Guzman and Stern (2019), while it is possible to found a new business without business registration (e.g., a sole proprietorship), the benefits of registration are substantial, and include limited liability, various tax benefits, the ability to issue and trade ownership shares, and credibility with potential customers. Business registrations reflect the population of incorporated 
businesses operating in a location (which may differ from their state of incorporation) that have taken on a form that is a pre-requisite for growth or employment. We define our main variable of interest, $\log (1+N e w$ Business Reg), as the natural logarithm of one plus the number of new business registrations in the county in the period of interest.

The SCP business registration data covers 50 states from 1988 to 2016, and 47 after 2014 (I.L., SC, and MI drop out of the sample after 2014). The SCP data is available at various levels of geographic aggregation (we use county level), but do not allow for identification of the firm's industry. All in all, $\log (1+$ New Business Reg $)$ complements $\log (1+$ Establishment Birth $)$ by providing a more refined measure of new business formation. Specifically, $\log (1+N e w$ Business Reg) avoids the limitation of the establishment birth measure, which may be driven by new branches of existing companies rather than new business formation. We graph the county variation of New Business Reg in Figure 2.

\section{Edgar Server Logs}

To directly examine the consumption of public firm disclosures, we retrieve the server logs associated with the SEC's Edgar website. We define $\log (1+$ Downloads $)$ as the natural logarithm of one plus the total number of downloads in a given county-quarter. The SEC's server log provides the Internet Protocol (I.P.) address (anonymized), a timestamp, and the physical location of the I.P. address. Our dataset covers the period from 2005 to 2017.

\section{Summary Statistics}

Table 1 provides descriptive statistics for our key variables. Panel A presents summary statistics at the county-industry-year level, while Panel B presents summary statistics at the county-quarter level. The average county-industry-year in our sample has 11 establishment births and the median observation has a public firm presence rank of 0.5 while $12 \%$ of the observations 
coming from counties with at least one IPO. Columns (2) and (3) of Panel A compares counties with at least one IPO vs. counties with no IPO activity during our sample period along the lines of establishment births, public firm presence, population and per capita income. Descriptively, we see that counties with at least one IPO tend to have more establishments, income per capita, and population.

The average county-quarter in our sample has 370 new business registrations with $2 \%$ of the observations occurring after an IPO in the county. The average annual income per capita in the sample is $\$ 26,669$ with an average income growth rate of $1 \%$. Columns (2) and (3) of Panel B, similarly to that of Panel A, show that counties with at least one IPO are observably different from counties with no IPOs. These differences motivate us to include county fixed effects as outlined in the next section. We also include income per capita, population, and the proportion of public firms as controls to account for these heterogeneities.

\section{RESULTS}

In this section we describe our empirical design as well as the results of our estimation of the relation between public firm disclosure and new business formation. We then conduct a number of tests to support information production as the mechanism for the positive relation documented in our analyses. Finally, we conclude with tests to rule out the alternative story that economic growth is driving our results rather than information from public disclosure.

\section{A. Public Firm Presence and New Business Formation}

We begin our analysis by examining the relation between public firm disclosures, as proxied by the Shroff et al. (2017) measure of public firm presence, and new business formation. To test whether entrepreneurial activity is influenced by public firm presence, we run the following regression: 


$$
\begin{aligned}
& \log (1+\text { Establishment Birth })_{c, i, t} \\
& \qquad \begin{array}{l}
=\delta \text { Pub Firm Presence Quintile } e_{i, t}+\alpha_{c}+\mu_{i}+\gamma_{t}+\beta^{\prime} X_{c, t}+\theta_{c} t+\varepsilon_{c, i, t}
\end{array}
\end{aligned}
$$

with observations measured at the county $c$, industry $i$, and year $t$ level. Establishment Birth ${ }_{c, i, t}$ is the number of new establishment births in the countyindustry-year, as taken from the Census database. Pub Firm Presence Quintile $e_{i, t}$ is the yearly quintile of the proportion of public firms for each NAICS 2-digit industry $i$ and year $t$, following Badertscher et al. (2013) and Shroff, Verdi, and Yost (2017). We include county $\propto_{c}$, industry $\mu_{i}$, and year $\gamma_{t}$ fixed effects, as well as a county-specific linear time trend $\theta_{c} t$. Finally, $X_{t, c}$ is a vector of time-varying county specific control variables, including the log of population and income per capita. We cluster standard errors at the county level. Our coefficient of interest, $\delta$, captures the percentage increase in entrepreneurial activity associated with a one quintile increase in public firm presence in an industry.

Table 2 provides the results of estimating equation (1). Column (1) demonstrates a positive

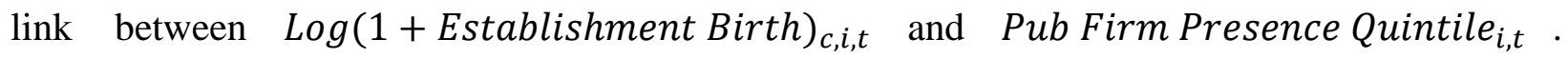
Column (2) shows that this relation is robust to including county-specific linear trends. Specifically, we find an 8-10\% increase in the number of establishment births for a one quintile increase of public firm presence in the industry. This translates into an increase in one establishment birth per year in the industry on average. Columns (3) and (4) similarly show that this relation is robust to using $\log (\text { Establishment Birth })_{c, i, t}$ as the dependent variable, where we restrict the sample solely to observations with positive establishment births.

In Table 3 we exploit changes in the information environment around IPOs to examine the relation between public firm disclosures and establishment births. Our identification strategy 
relies on IPOs representing a significant improvement in the information environment, with the information being more prominent for entrepreneurs in the local county. Specifically, we run the following specification:

$$
\log (1+\text { Establishment Birth })_{c, i, t}=\text { SPost IPO } O_{c, t}+\propto_{c}+\mu_{i}+\gamma_{t}+\beta^{\prime} X_{t, c}+\theta_{c} t+\varepsilon_{c, i, t}
$$

for county $c$, industry $i$, and year $t$. Post $I P O_{c, t}$ is an indicator variable that equals one for a given county in the years following an IPO, and zero otherwise. We include county fixed effects $\propto_{c}$, year fixed effects $\gamma_{t}$, industry fixed effects $\mu_{i}$, and county-specific linear time trend $\theta_{c} t$. Control variables include the log of county population and county income per capita. We cluster the standard errors at the county level.

Table 3 Panel A reports the results based on equation (2). Columns (1) and (2) document a significant positive association between $\log (1+\text { Establishment Birth })_{c, i, t}$ and Post IPO $O_{c, t}$. Columns (3) and (4) show that this positive association is robust to using $\log (\text { Establishment Birth })_{c, i, t}$ as the main dependent variable and restricting solely to observations in which Establishment Birth $h_{c, i, t}>0$. We observe an 11-22\% increase in the number of establishment births post IPO, depending on the specification. To provide economic context, Post $I P O_{c, t}$ county-years realize an increase of around one new establishment per year relative to non-IPO county-years on average.

We also examine the specific role of information in driving the relation between IPOs and new business formation in Panels B and C of Table 3. Specifically, we partition IPOs into IPOs in the same industry as the establishment (Panel B) versus IPO firms in a different industry to the establishment (Panel C). We then rerun the specifications in Panel A with the new Post IPO variables based on whether the IPO and establishments are in the same industry as IPO firm or 
not. Our partitioning of same vs. different industry is based on the notion that the information produced by IPOs in similar industries is expected to generate more relevant information spillovers for potential entrepreneurs.

The results in Panels B and $\mathrm{C}$ suggest that the documented increase in establishment births in Panel A is primarily driven by IPOs in the same industry as opposed to those that are in different industries. For example, we observe roughly a $30 \%$ increase in new establishment births when the IPO is in the same industry, compared to a more modest $2 \%$ (and statistically insignificant) effect when the IPO is in a different industry. This heterogeneity in response corroborates the hypothesis that information spillovers from public firm disclosures is responsible for facilitating entrepreneurial activity and new business formation.

A notable caveat to our tests using Establishment Births is that establishments do not necessarily represent true entrepreneurial activity, but rather may simply reflect existing firms' expansions. To address this issue, we next exploit the SCP dataset and measure new business formation using New Business Registrations. Our identification strategy relies on a difference-indifference framework utilizing IPOs at the county level to capture the additional information provision provided by the emergence of a new public firms. Note that we can no longer have an industry dimension for these tests due to lack of data in the SCP database. Hence, in the estimation below, our identification strategy comes from variation across counties. Specifically, we estimate the following specification:

$$
\log (1+\text { New Business Reg })_{c, q}=\delta \text { Post } I P O_{c, q}+\propto_{c}+\gamma_{q}+\beta^{\prime} X_{c, q}+\theta_{c} q+\varepsilon_{c, q}
$$

for county $c$ and quarter $q$. New Business $\operatorname{Reg}_{c, q}$ is the number of new business registrations as reported in the SCP database. Post $I P O_{c, q}$ is an indicator variable that equals one for the county- 
quarters after an IPO and zero otherwise. We include county fixed effects $\propto_{c}$, quarter-year fixed effects $\gamma_{q}$, and county-specific linear time trends $\theta_{c} q$. Control variables include the log of county population and county income per capita. We cluster the standard errors at the county level. This design compares changes in new business registrations in county quarters where an IPO has been initiated to business registrations in county quarters without an IPO.

Table 4 Panel A reports the results of estimating variations of equation (3). In columns (1) and (2) our main dependent variable is $\log \left(1+\right.$ New Business $\left.\operatorname{Reg}_{c, q}\right)$ while in column (3) we use $\log \left(\right.$ New Business $\left.\operatorname{Reg}_{c, q}\right)$ as our main dependent variable and restrict the sample to non-zero observations. Consistent with our establishment birth results, in Panel A, we find that areas that experience an IPO see an increase of 4-9\% in new business registrations in the quarters after the IPO. This increase translates to around 14 to 33 new business registrations on average in the post IPO quarters relative to non-IPO quarters. Figure 3 graphs the coefficients in event time around the IPO; the graph suggests that the parallel trends assumption holds in our D.D. specifications around the IPO.

In Table 4 Panel B, we explore the temporal variation of the effect of IPOs on new business formation, re-estimating the specification in column (2) of Panel A, and varying the timing of the measurement of new business registrations. Specifically, we use the number of new business registrations four (4) quarters ahead in column (1), five (5) quarters ahead in column (2), six (6) quarters ahead in column (3), and the cumulative number of registrations between 4-6 quarters ahead in column (4). We find a consistently positive relation between IPOs and new business registrations between 4 to 6 quarters out. The $9 \%$ increase is consistent with the findings in the first three columns. When we examine the cumulative number of business registrations in 
column (4), we document a significant $7 \%$ increase in cumulative new business registrations after the IPO.

\section{B. Public Firms and Entrepreneurial Interest}

We have so far documented a positive link between our public firm disclosure proxies and business formation. We now turn to a measure that captures the general interest of business formation more broadly: internet searches for terms and phrases directly related to launching a business - entrepreneurial interest (Barrios et al., 2020). ${ }^{5}$ This measure provides us with a timelier response to information spillover from the IPO by examining whether the exposure to the new firm's disclosures leads individuals to begin contemplating entrepreneurship. By doing so, the measure also helps us directly examine whether the positive business formation effect is driven by individual interests in forming new businesses as implied by our hypothesis.

Table 5 employs a linear probability model with the outcome being an indicator variable that is defined as one in the case that the DMA is in the top quartile of entrepreneurial search in that quarter. Each specification includes controls for population, per capita income, and the number of public firms headquartered in the area. Our variable of interest is the PostIPO variable, which captures exposure to public firm information being produced by the IPO. Column (1) includes year and state fixed effects while in Column (2), we include state-specific linear trends. Results from both specifications indicate that after an IPO, the affected county is more likely to be in the

\footnotetext{
${ }^{5}$ We track trends for searches for these terms using the Google Health Trends API for all Nielsen Designated Market Areas (DMAs) at monthly frequency from January 2004 to December 2016. We aggregate the data to the quarter level and match the DMAs to Census incorporated places using a crosswalk provided by Nielsen. Specifically, we use the terms: "start a business," "start your own business," "start a company," "how to incorporate," "entrepreneurship," "become an entrepreneur," and "small business loan." See Barrios et al. (2020) for more details.
} 
highest quartile of entrepreneurial search activity. In terms of economic magnitude, the $1.5 \%$ increase in the probability translates to a $6 \%$ increase over the base probability of $25 \%$.

\section{Mechanism Tests: Information and Economic Uncertainty}

We validate our primary mechanism of information disclosure by exploiting variation in the amount of new information produced around an IPO. We do so by examining IPOs of private firms and IPOs of subsidiaries of already public firms (i.e., spinoffs). Our basis for examining these two distinct types of IPOs is motivated by the fact that more new information is provided to external parties from private firms going public than when a subsidiary of a public firm goes public. When a subsidiary is spun off and goes public, less information is arguably generated, as the parent corporation was already producing disclosures covering the subsidiary. On the margin, the amount of new information being produced should be lower in a spinoff than in the case of an IPO of a private firm who has previously not disclosed any information to the public.

We examine the differential effects of these two types of IPOs on new business registrations empirically in Table 6. Specifically, we re-estimate equation (3), where the outcome of interest is $\log \left(1+\right.$ New Business $\left.\operatorname{Reg}_{c, q}\right)$ and our independent variable of interest is two variations of PostIPO. In column (1) we define Post Public IPO as an indicator variable that is set to one in county quarters after a subsidiary of an already public firm goes public, whereas in column (2), Post Private IPO is defined based on the IPOs of private firms that go public. Each specification includes county and year-quarter fixed effects and controls for population and per capita income. We observe that both private and public IPOs are positively related with new business formation, however, consistent with more information being produced around private firms going public, we observe that the coefficient on Post Private IPO (.27) is more than $45 \%$ larger than that of the

Post Public IPO (.18). This differential effect on new business formation provides evidence that 
suggests information disclosure is driving the positive relation between IPO and new business formation.

Next, we examine a case where public firm information may be more valuable to entrepreneurs: locations where economic uncertainty (and in turn, entrepreneurial income uncertainty), is higher. ${ }^{6} \mathrm{We}$ operationalize the economic uncertainty proxy by constructing a measure of the volatility in wage growth in each county (Barrios et al., 2020). ${ }^{7}$ We utilize data from the Bureau of Labor Statistics (BLS) Quarterly Census of Employment and Wages (QCEW) for this purpose. Wage growth volatility is computed as the sum of the variances and covariances of the wage growth rate in the various industry sectors, weighted by the employment share of each individual sector. We compute this measure at the county level.

For our computations, we derive a variance-covariance matrix from a trend-adjusted time series of county-industry employment data. Mathematically, the measure of wage growth volatility for the portfolio of industries in a given county is then expressed as:

$$
\sigma_{c}^{2}=\sum_{i} w_{i}^{2} \sigma_{i}^{2}+\sum_{i \neq j} \sum_{i \neq j} w_{i} w_{j} \sigma_{i j}
$$

where $w_{j}$ denotes the proportion of total employment in industry $\mathrm{j}, \sigma_{j}^{2}$ denotes the variance of wage growth rate in industry $\mathrm{j}$, and $c$ denotes county. In Figure 4, we graph the relationship between our wage growth volatility measure and new business registration. We absorb time and location fixed effects. As the scatter plot demonstrates, the relationship between wage growth volatility and entrepreneurial entry is negative, consistent with economic uncertainty discouraging entrepreneurial activity.

\footnotetext{
${ }^{6}$ Conceptually, we can think of economic profits as reflecting demand shocks to industries, which in turn also lead to variation in wage growth. Under a rent-sharing perspective, whenever there is a demand shock that leads to change in profits, this change is shared between the firm and labor (Kline et al., 2019).

${ }^{7}$ Ideally, we would use variation in economic profits in an area to proxy for economic uncertainty, but data on business profits is unavailable
} 
In Table 7 Panel B, we utilize our proxy for economic uncertainty - the volatility of wage growth in the county - and estimate similar interacted models in equation (3), but including the interaction of a standardized version of our ex-ante uncertainty measure with the POST IPO variable in the models. We measure wage growth volatility for each county using all quarters up to the quarter before entry (or all quarters, if no entry occurs during the sample period). Because this measure in not at the annual level, but rather measured once per county, the lower order term (pre-entry wage growth volatility itself) is absorbed by the county fixed effects. Consistent with our conceptual framework, the models in Table 7 indicate that the positive effects of the IPOs on new business formation are concentrated in counties with higher ex-ante economic uncertainty, translating into an additional 40 percentage point increase in new business registrations for the top quartile of ex-ante economic uncertainty, on top of the main effect IPOs. The effect in counties in the top quartile of ex-ante uncertainty (1.93\%) is about five times larger than the average of the bottom three quartiles of ex-ante economic uncertainty $(0.48 \%)$. This bolsters the view that the public firm disclosures provide valuable information for potential entrepreneurs.

An important implied relation of the positive link between our disclosure proxy (IPO) and new business formation is that we should expect more intense information acquisition patterns as a result of the IPO event. In Table 8, Panel A we examine the relation between Edgar searches from the county around IPOs. Edgar searches are measured by the number of public disclosure files downloaded from the Edgar website at the county-year level. Each specification includes year and county fixed effects as well as controls for population and per capita income in the county. Column 1 uses the $\log \left(1+\right.$ Downloads $\left._{c, q}\right)$ while in column (2) we replace the outcome with $\log \left(\right.$ Downloads $\left._{c, q}\right)$ and restrict to non-zero observations. Both specifications show a consistent significant positive effect of IPOs on the number of downloads from Edgar in the 
county. We document a $27 \%$ increase in Edgar downloads in post IPO quarters in the county. This increase translates into an average increase of 34,000 downloads a quarter post IPOs.

In Table 8 Panel B, we examine whether these Edgar searches are related to increases in new business formation. Specifically, we regress $\log (1+\text { New Business Reg })_{c, q}$ on $\log (1+$ Downloads $\left._{c, q}\right)$ in column 1 and on $\log \left(\right.$ Downloads $\left._{c, q}\right)$ in column 2. For both columns, we find a positive link between Edgar searches and new business registrations. For economic context, this means that a doubling Edgar searches is associated with a $1 \%$ increase in new business formation. These findings are consistent with the view of public firm disclosures informing entrepreneurs, further raising the bar for an alternative mechanism, such as industry growth prospects, to explain our results.

\section{Are We Just Capturing County Growth?}

Despite our strict model specifications and additional analyses that collectively support an information story, we recognize that economic growth in counties is an important confounding factor with respect to both IPOs and new business formation. We attempt to further assuage these concerns by examining whether there is evidence that economic growth (as proxied by local employment wages) may be driving our results. In Table 9, we estimate models using average weekly wage as the outcome measure, using a similar specification to the previous analyses. We fail to document significant increases in average weekly wages post IPOs, suggesting that our observed increases in entrepreneurial activity surrounding an IPO are unlikely to be solely driven by the growth of the local economy. 


\section{CONCLUSION}

One of the fundamental questions in accounting is whether and to what extent financial reporting facilitates the allocation of capital to investment opportunities (Roychowdhury, Shroff, and Verdi, 2019). To date, the primary focus of the literature on the public disclosure learning channel has been on the intensive margin - the investment efficiency of the firm itself. In this paper, we build upon this work and explore how public firm disclosure may affect learning on the extensive margin, in the form of new business formation. Specifically, we consider whether firms' public accounting disclosures provide information that can potentially inform entrepreneurs in their decisions to start a new business. Our findings suggest that the provision of information from public firm disclosures reduces uncertainty related to entrepreneurial income volatility, thus increasing entrepreneurial activity, and galvanizing would-be entrepreneurs to engage in new business formation.

Our results contribute to the fundamental question of improving new business formation. Economists since Adam Smith have emphasized the importance of entrepreneurs and new business formation to the economy. Policymakers continuously seek for ways to stimulate entrepreneurial activity in their local regions. In this paper, we shed light on new business formation through the positive spillover effects of public firm disclosures on entrepreneurial activity. 


\section{REFERENCES}

Admati, A. R. and P. Pfleiderer (2000). Forcing firms to talk: Financial disclosure regulation and externalities. The Review of Financial Studies 13 (3), 479-519.

Armstrong, C. S., W. R. Guay, and J. P. Weber (2010). The role of information and financial reporting in corporate governance and debt contracting. Journal of Accounting and Economics 50(2-3), 179-234.

Alvarez, S. A. and J. B. Barney (2007). Discovery and Creation: Alternative Theories of Entrepreneurial Action. Strategic Entrepreneurship Journal 1, 11-26.

Alvarez, S.A., and J. B. Barney, and P. Anderson. Forming and Exploiting Opportunities: The Implications of Discovery and Creation Processes for Entrepreneurial and Organizational Research. Organization Science 24(1), 301-317.

Badertscher, B., N. Shroff, and H. D. White (2013). Externalities of public firm presence: Evidence from private firms' investment decisions. Journal of Financial Economics 109(3), 682-706.

Barrios, J. M., Y. V. Hochberg, and H. Yi (2020). Launching with a parachute: The gig economy and entrepreneurial entry. University of Chicago, Becker Friedman Institute for Economics Working Paper (2020-21).

Beatty, A., S. Liao, and J. J. Yu (2013). The spillover effect of fraudulent financial reporting on peer firms' investments. Journal of Accounting and Economics 55 (2- 3), 183-205.

Berger, P. G. (2011). Challenges and opportunities in disclosure research - a discussion of 'the financial reporting environment: Review of the recent literature'. Journal of Accounting and Economics 51 (1-2), 204-218.

Beyer, A., D. A. Cohen, T. Z. Lys, and B. R. Walther (2010). The financial reporting environment: Review of the recent literature. Journal of Accounting and Economics 50(2-3), 296-343.

Bloom, N. (2009). The Impact of Uncertainty Shocks. Econometrica 77, 623-685.

Breuer, M. (2018). "How Does Financial-Reporting Regulation Affect Market-Wide Resource Allocation?" Working Paper.

David, J., Hugo, H., and Venkateswaran, V. (2016). Information, Misallocation, and Aggregate Productivity. Quarterly Journal of Economics 131, 943-1005.

Decker, R., J. Haltiwanger, R. Jarmin, and J. Miranda (2014). The role of entrepreneurship in us job creation and economic dynamism. Journal of Economic Perspectives 28(3), 3-24.

Durnev, A. and C. Mangen (2009). Corporate investments: Learning from restatements. Journal of Accounting Research 47 (3), 679-720.

Guzman, J. and S. Stern (2015). Where is silicon valley? Science 347(6222), 606-609. 
Guzman, J., \& Stern, S. (2019). The State of American Entrepreneurship: New Estimates of the Quality and Quantity of Entrepreneurship for 32 U.S. States, 1988-2014. (No. w22095). National Bureau of Economic Research.

Haltiwanger, J., R. S. Jarmin, and J. Miranda (2013). Who creates jobs? small versus large versus young. Review of Economics and Statistics 95 (2), 347-361.

Hamilton, R. (2001). E-commerce new venture performance: how funding impacts culture. Internet Research.

Healy, P. M. and K. G. Palepu (2001). Information asymmetry, corporate disclosure, and the capital markets: A review of the empirical disclosure literature. Journal of Accounting and Economics 31(1), 405 -440 .

Hurst, E. and B. W. Pugsley (2011). What do small businesses do? (No. w17041). National Bureau of Economic Research.

Kerr, W. R., J. Lerner, and A. Schoar (2014). The Consequences of Entrepreneurial Finance: Evidence from Angel Financings. Review of Financial Studies 27(1), 20-55.

Kim, $\mathrm{J}$ and Valentine, K, The Innovation Consequences of Mandatory Patent Disclosures (2020). Working Paper. 1-60.

Kirzner, I. M. (2015). Competition and entrepreneurship. University of Chicago press.

Lambert, R. A. (2001). Contracting theory and accounting. Journal of Accounting and Economics 32(13), 3-87.

Leuz, C. and P. D. Wysocki (2016). The economics of disclosure and financial reporting regulation: Evidence and suggestions for future research. Journal of Accounting Research 54(2), 525-622.

Liberti, José María and Petersen, Mitchell A (2019). Information: Hard and Soft, The Review of Corporate Finance Studies, Volume 8, Issue 1, March 2019, Pages 1-41,

Roychowdhury, S., N. Shroff, and R. S. Verdi (2019). The effects of financial reporting and disclosure on corporate investment: A review. Journal of Accounting and Economics 68(2-3), 101246.

Ryans, James (2017), Using the EDGAR Log File Data Set. Working Paper, 1-36.

Shroff, N., R. S. Verdi, and B. P. Yost (2017). When does the peer information environment matter? Journal of Accounting and Economics 64 (2-3), 183-214.

Shroff, N., R. S. Verdi, and G. Yu (2014). Information environment and the investment decisions of multinational corporations. The Accounting Review 89(2), 759-790.

Verrecchia, R. E. (2001). Essays on disclosure. Journal of Accounting and Economics 32(1), 97 - 180. 


\section{TABLES AND FIGURES}

Figure 1 Distribution of IPOs by County

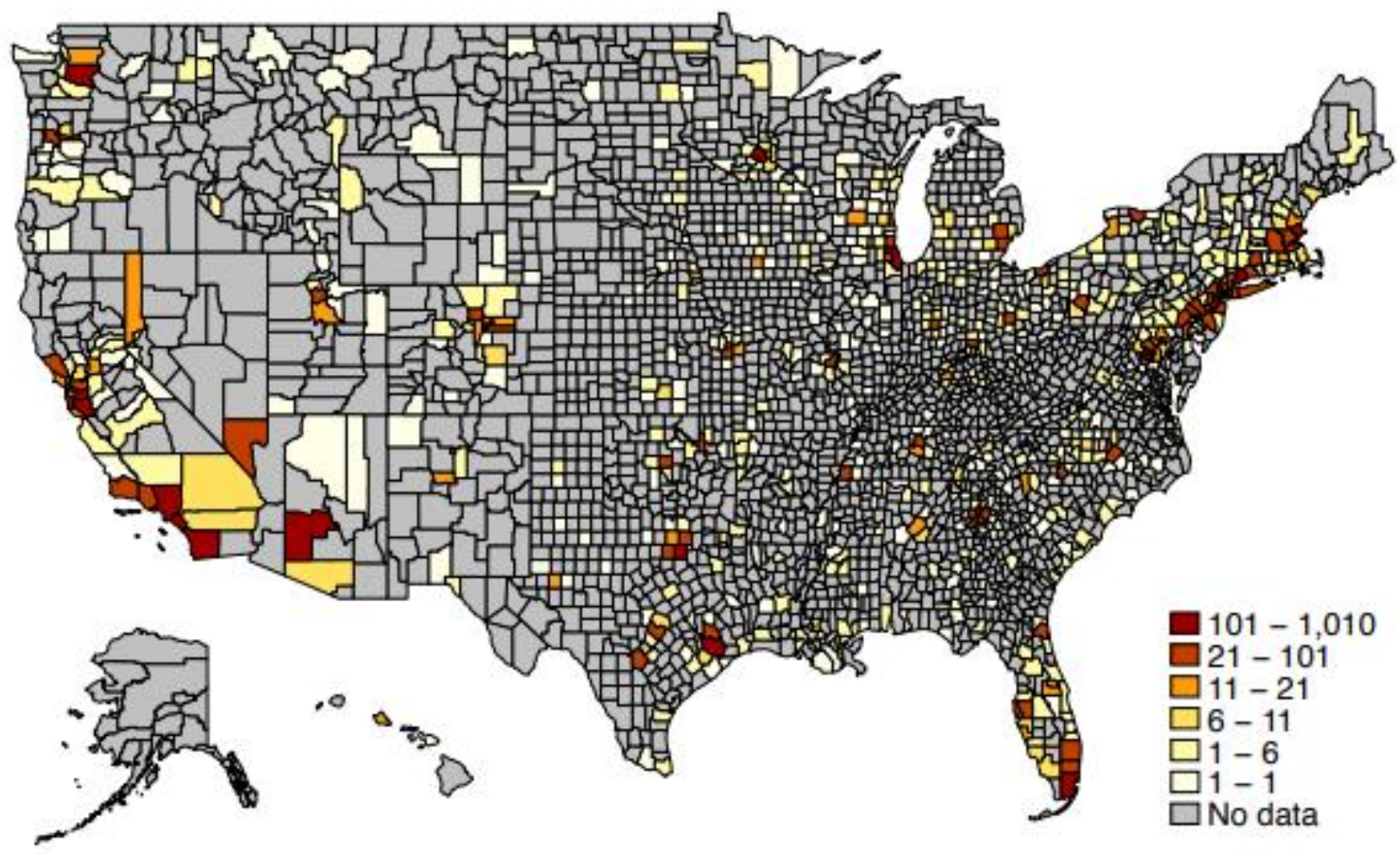

Notes: This figure plots the geographic distribution of 10,734 IPOs across U.S. Counties. The sample period is from 1985 Q1 to 2019 Q4. 


\section{Figure 2 New Business Registration by County}

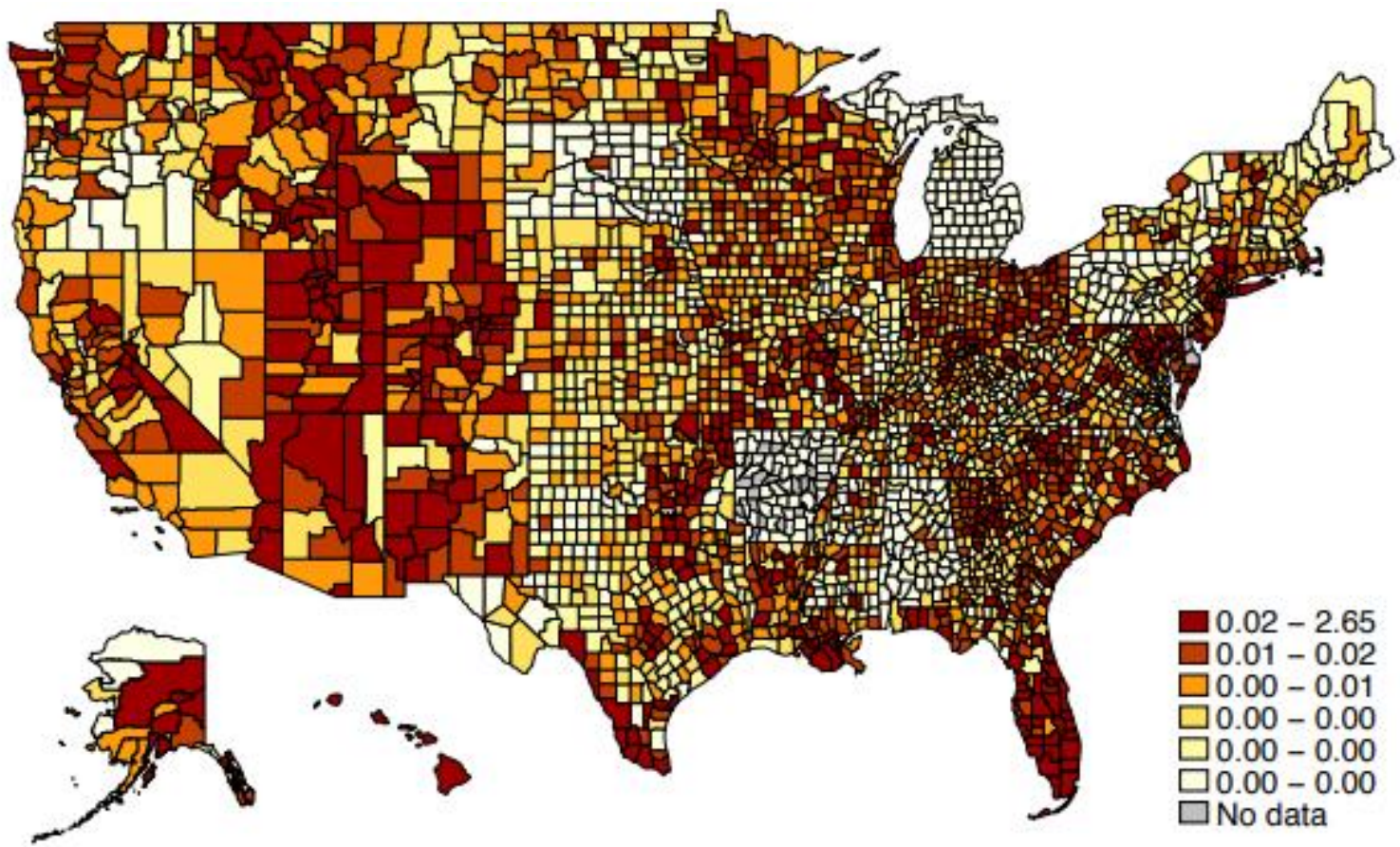

Notes: This figure plots the geographical distribution of annual average new business registration per capita across U.S. Counties. The sample period is from 1988 to 2016. 


\section{Figure 3 Parallel Trends of New Business Registration around IPO Event}

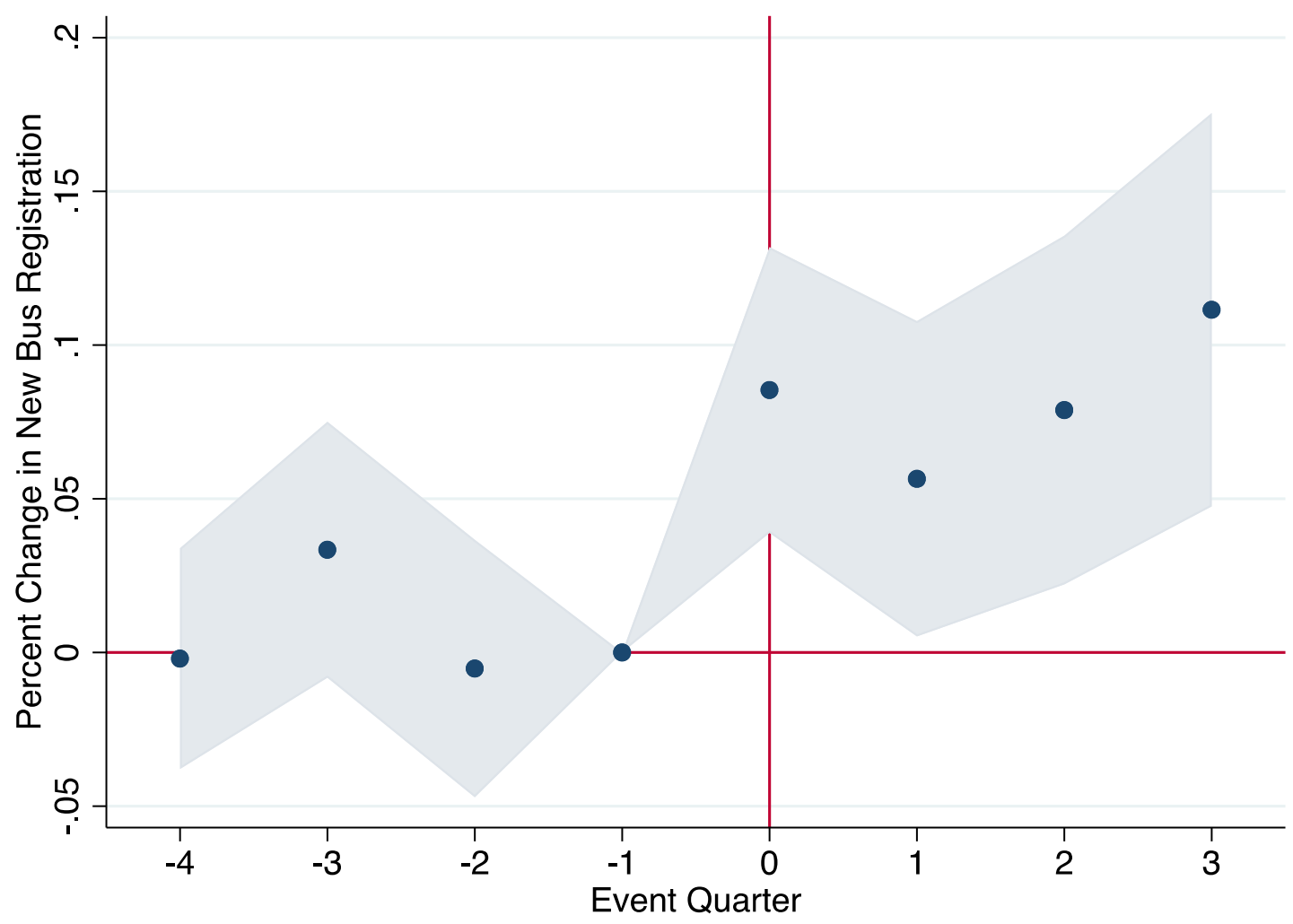

Notes: This figure plots the regression coefficient estimates of Model (3) in 8 quarters around the event window. Each dot is a point estimate of $\delta$ in equation (3) by shifting Post from Post $\mathrm{q}_{-4}$ to Post ${ }_{\mathrm{q}+3}$. The shaded region represents two-tailed $95 \%$ confidence intervals based on standard errors clustered at the county level. 
Figure 4 Economic Uncertainty and New Business Registration

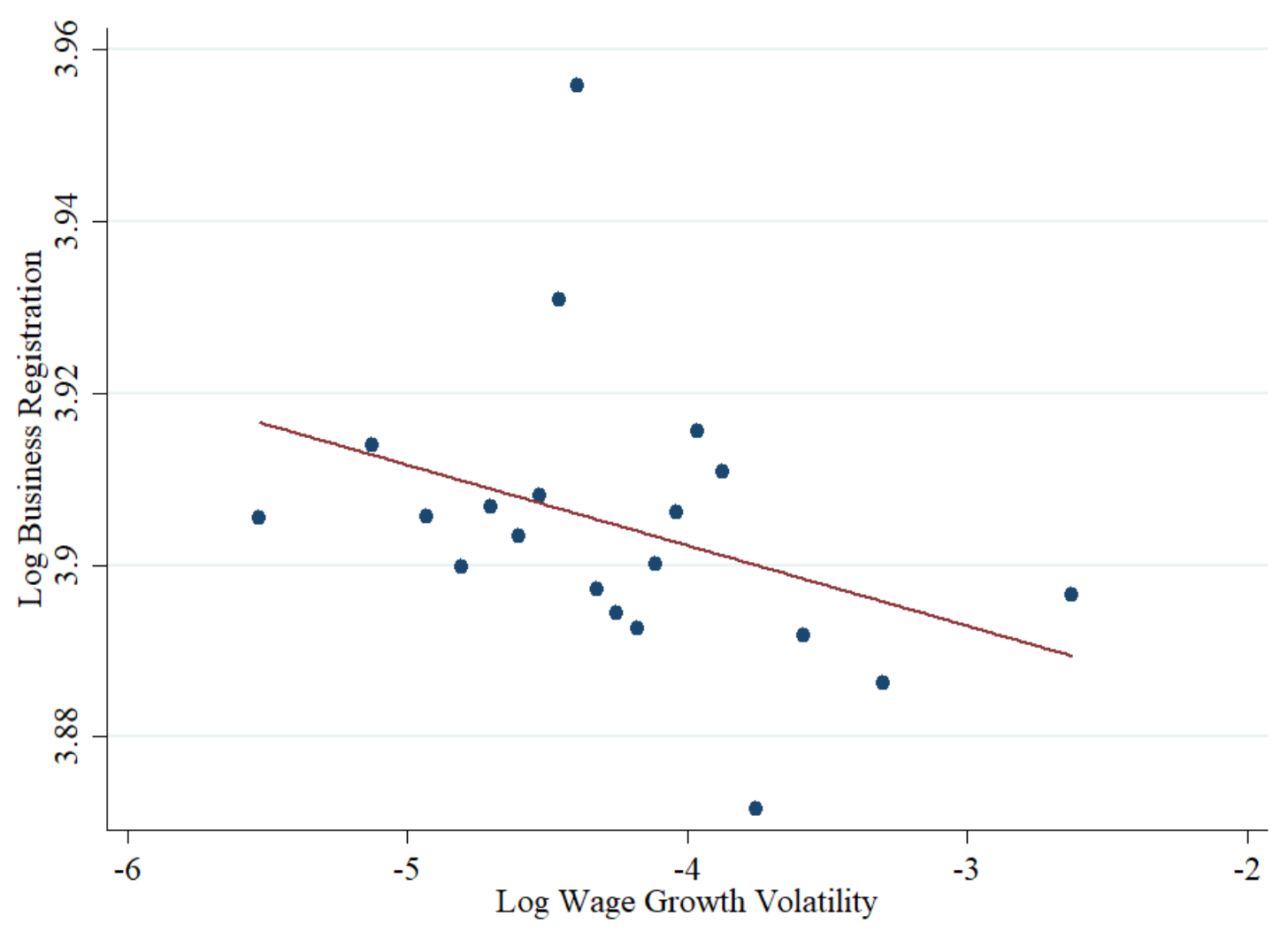

Notes: The figure plots the relationship between wage growth volatility and new business registration. Wage growth volatility at the county level is computed as the sum of the variances and covariances of the wage growth rate in the various industry sectors, weighted by the employment share of each individual sector in the county. We absorb time and location. 
Table 1. Descriptive Statistics

Panel A. County-Industry-Year data

\begin{tabular}{|c|c|c|c|c|c|c|c|c|c|c|c|c|}
\hline & \multicolumn{4}{|c|}{ (1) } & \multicolumn{4}{|c|}{ (2) } & \multicolumn{4}{|c|}{$(3)$} \\
\hline & count & mean & sd & p50 & count & mean & sd & p50 & count & mean & sd & p50 \\
\hline Establishment Birth & 783729 & 11.03 & 30.34 & 2.00 & 97564 & 54.83 & 67.94 & 23.00 & 778937 & 5.09 & 11.95 & 1.00 \\
\hline Public Firm Presence & 783729 & 0.47 & 0.35 & 0.50 & 85791 & 0.47 & 0.35 & 0.50 & 697938 & 0.47 & 0.35 & 0.50 \\
\hline Income Per Capita & 782967 & 31701.09 & 9860.90 & 29871.00 & 97548 & 41314.09 & 14481.83 & 38558.00 & 778078 & 31155.63 & 8925.55 & 29628.00 \\
\hline County Population & 783091 & 100878.94 & 318905.54 & 27321.00 & 97564 & 550525.19 & 819491.07 & 336794.00 & 778186 & 46691.58 & 68376.61 & 23773.00 \\
\hline Observations & 783729 & & & & 97564 & & & & 778937 & & & \\
\hline
\end{tabular}

\section{Panel B. County-Quarter Data}

\begin{tabular}{|c|c|c|c|c|c|c|c|c|c|c|c|c|}
\hline & \multicolumn{4}{|c|}{ (1) } & \multicolumn{4}{|c|}{ (2) } & \multicolumn{4}{|c|}{ (3) } \\
\hline & \multicolumn{4}{|c|}{ All } & \multicolumn{4}{|c|}{ County: At Least 1 IPO } & \multicolumn{4}{|c|}{ County: No IPO } \\
\hline & count & mean & sd & p50 & count & mean & sd & p50 & count & mean & $\mathrm{sd}$ & p50 \\
\hline New Business Registration & 360760 & 370.44 & 2451.24 & 17.00 & 75864 & 1314.81 & 4631.68 & 173.00 & 284896 & 118.96 & 1263.08 & 11.00 \\
\hline Public Firm in Area & 360760 & 0.10 & 1.06 & 0.00 & 75864 & 0.46 & 2.28 & 0.00 & 284896 & 0.00 & 0.07 & 0.00 \\
\hline IPO & 360760 & 0.02 & 0.26 & 0.00 & 75864 & 0.10 & 0.55 & 0.00 & 284896 & 0.00 & 0.00 & 0.00 \\
\hline Income Per Capita & 359900 & 26669.74 & 11180.97 & 24808.00 & 75808 & 31517.61 & 13474.87 & 29341.00 & 284092 & 25376.12 & 10098.41 & 23758.00 \\
\hline Income Growth & 356793 & 0.01 & 0.03 & 0.00 & 75154 & 0.01 & 0.03 & 0.00 & 281639 & 0.01 & 0.04 & 0.00 \\
\hline Population & 360364 & 91950.60 & 314338.54 & 24856.00 & 75808 & 316598.01 & 632045.07 & 138324.50 & 284556 & 32102.73 & 41010.29 & 19030.00 \\
\hline Population Growth & 357254 & 0.00 & 0.02 & 0.00 & 75154 & 0.00 & 0.02 & 0.00 & 282100 & 0.00 & 0.02 & 0.00 \\
\hline Observations & 360760 & & & & 75864 & & & & 284896 & & & \\
\hline
\end{tabular}

Notes: This table presents summary statistics for the sample of establishment birth data from the Census (Panel A) and new business registration data from the Startup Cartography Project (Panel B). Panel A is at the county-industry-year level. Panel B is at the county-quarter level. In both panels, Columns (2) and (3) show these statistics across counties with at least one IPO vs. counties with no IPO activity. 
Table 2. Public Firm Presence and Establishment Births

(1)

\begin{tabular}{|c|c|c|c|c|}
\hline Pub Firm Presence Quintile & $\begin{array}{c}0.0890 * * * \\
(0.0096)\end{array}$ & $\begin{array}{c}0.0898 * * * \\
(0.0096)\end{array}$ & $\begin{array}{c}0.1030 * * * \\
(0.0157)\end{array}$ & $\begin{array}{c}0.1037 * * * \\
(0.0158)\end{array}$ \\
\hline Log(Income Per Capita) & $\begin{array}{c}0.2545^{* * * *} \\
(0.0173)\end{array}$ & $\begin{array}{c}0.0987 * * * \\
(0.0127)\end{array}$ & $\begin{array}{c}0.3490 * * * \\
(0.0273)\end{array}$ & $\begin{array}{c}0.1603 * * * \\
(0.0209)\end{array}$ \\
\hline Log(Population) & $\begin{array}{c}0.3870 * * * \\
(0.0230)\end{array}$ & $\begin{array}{c}0.3698 * * * \\
(0.0461)\end{array}$ & $\begin{array}{c}0.5386^{* * * *} \\
(0.0296)\end{array}$ & $\begin{array}{c}0.4873 * * * \\
(0.0669)\end{array}$ \\
\hline Observations & 782,850 & 782,850 & 552,868 & 552,868 \\
\hline Year F.E. & Yes & Yes & Yes & Yes \\
\hline County F.E. & Yes & Yes & Yes & Yes \\
\hline NAICS2 & Yes & Yes & Yes & Yes \\
\hline MSA Year Trend & No & Yes & No & Yes \\
\hline Cluster & County & County & County & County \\
\hline Adjusted R-squared & 0.784 & 0.784 & 0.795 & 0.796 \\
\hline
\end{tabular}


Table 3. IPOs and Establishment Births

Panel A. All IPOs

(1)

(2)

(3)

(4)

$\log (1+$ Establishment Birth $) \quad \log (1+$ Establishment Birth $) \quad \log ($ Establishment Birth $) \quad \log ($ Establishment Birth $)$

$\begin{array}{lcccc}\text { Post IPO } & 0.1475 * * * & 0.2240 * * * & 0.1172 * * * & (0.0249) \\ & (0.0307) & (0.0312) & & 0.1629 * * * \\ & & & 604,709 & 60266) \\ \text { Observations } & 875,506 & 875,506 & \text { Yes } & \text { Yes } \\ \text { Year F.E. } & \text { Yes } & \text { Yes } & \text { Yes } & \text { Yes } \\ \text { County F.E. } & \text { Yes } & \text { Yes } & \text { Yes } & \text { Yes } \\ \text { NAICS2 } & \text { Yes } & \text { Yes } & \text { No } & \text { Yes } \\ \text { County Year Trend } & \text { No } & \text { Industry-Year } & \text { Industry-Year } & \text { Industry-Year } \\ \text { Cluster } & \text { Industry-Year } & 0.891 & 0.792 & 0.910 \\ \text { Adjusted R-squared } & 0.781 & & \end{array}$

Panel B. Same Industry IPOs

(1)

(2)

(3)

(4)

$\log (1+$ Establishment Birth $) \quad \log (1+$ Establishment Birth $) \quad \log ($ Establishment Birth $) \quad \log ($ Establishment Birth $)$

\begin{tabular}{|c|c|c|c|c|}
\hline Post Same Industry IPO & $\begin{array}{c}0.3979 * * * \\
(0.0493)\end{array}$ & $\begin{array}{c}0.4014 * * * \\
(0.0525)\end{array}$ & $\begin{array}{c}0.2869 * * * \\
(0.0411)\end{array}$ & $\begin{array}{c}0.2846 * * * \\
(0.0429)\end{array}$ \\
\hline Observations & 875,506 & 875,506 & 604,709 & 604,709 \\
\hline Year F.E. & Yes & Yes & Yes & Yes \\
\hline County F.E. & Yes & Yes & Yes & Yes \\
\hline NAICS2 & Yes & Yes & Yes & Yes \\
\hline County Year Trend & No & Yes & No & Yes \\
\hline Cluster & Industry-Year & Industry-Year & Industry-Year & Industry-Year \\
\hline Adjusted R-squared & 0.782 & 0.783 & 0.793 & 0.794 \\
\hline
\end{tabular}


Table 3 [Continued]

Panel C. Different Industry IPOs

(7)

(8)

$\log (1+$ Establishment Birth $) \quad \log (1+$ Establishment Birth $) \quad \log ($ Establishment Birth $) \quad \log ($ Establishment Birth $)$

\begin{tabular}{|c|c|c|c|c|}
\hline Post Different Industry IPO & $\begin{array}{c}0.0158 \\
(0.0416)\end{array}$ & $\begin{array}{c}0.0097 \\
(0.0322)\end{array}$ & $\begin{array}{c}0.0199 \\
(0.0316)\end{array}$ & $\begin{array}{c}0.0026 \\
(0.0275)\end{array}$ \\
\hline Observations & 875,506 & 875,506 & 604,709 & 604,709 \\
\hline Year F.E. & Yes & Yes & Yes & Yes \\
\hline County F.E. & Yes & Yes & Yes & Yes \\
\hline NAICS2 & Yes & Yes & Yes & Yes \\
\hline County Year Trend & No & Yes & No & Yes \\
\hline Cluster & Industry-Year & Industry-Year & Industry-Year & Industry-Year \\
\hline Adjusted R-squared & 0.781 & 0.782 & 0.792 & 0.794 \\
\hline
\end{tabular}

Notes: This table reports estimation of Model (2) that regresses the number of new establishment births on IPOs. Panel A reports the results of IPOs from all industries. Panel B reports the results of IPOs from the same industry as the new establishments. Panel C reports the results of IPOs from industries different from the new establishments. Establishment Birth is the number of new establishments in an industry and county-year. Post IPO is an indicator variable that equals one if a county has an IPO in the past, and zero otherwise. $\log ($ Income Per Capita) is the log of income per capita at the county-year level. $\log ($ Population) is the number of population at the county-year level. Standard errors clustered at the county level are reported in the parentheses. ***, **, and * mark statistical significance at $1 \%, 5 \%$, and $10 \%$, respectively. 
Table 4. IPOs and New Business Registrations

Panel A. Measurement period of New Business Registration begins at IPO quarter

\begin{tabular}{|c|c|c|c|}
\hline & $\begin{array}{c}(1) \\
\log (1+\text { New Business Reg })\end{array}$ & $\begin{array}{c}(2) \\
\log (1+\text { New Business Reg }) \\
\end{array}$ & $\begin{array}{c}\text { (3) } \\
\log (\text { New Business Reg) }\end{array}$ \\
\hline Post IPO & $\begin{array}{l}0.1020 * * * \\
(0.0385)\end{array}$ & $\begin{array}{c}0.0978 * * \\
(0.0432)\end{array}$ & $\begin{array}{c}0.0458 * * \\
(0.0195)\end{array}$ \\
\hline Log Population & $\begin{array}{l}0.9508 * * * \\
(0.0510)\end{array}$ & $\begin{array}{l}0.5641 * * * \\
(0.0623)\end{array}$ & $\begin{array}{l}0.6500 * * * \\
(0.0523)\end{array}$ \\
\hline Log Income Per Capita & $\begin{array}{l}0.5863 * * * \\
(0.0582)\end{array}$ & $\begin{array}{l}0.5850 * * * \\
(0.0397)\end{array}$ & $\begin{array}{l}0.6611 * * * \\
(0.0382)\end{array}$ \\
\hline Log Num Pub Firm in Area & $\begin{array}{l}0.0903^{*} \\
(0.0464)\end{array}$ & $\begin{array}{c}0.0566 \\
(0.0400)\end{array}$ & $\begin{array}{c}0.0123 \\
(0.0100)\end{array}$ \\
\hline $\begin{array}{l}\text { Observations } \\
\text { Year-Quarter FE } \\
\text { County F.E. } \\
\text { County Specific Y.Q. Trend } \\
\text { Sample } \\
\text { Adjusted R-squared }\end{array}$ & $\begin{array}{c}359,892 \\
\text { Yes } \\
\text { Yes } \\
\text { No } \\
\text { Issuance Date } \\
0.891\end{array}$ & $\begin{array}{c}359,892 \\
\text { Yes } \\
\text { Yes } \\
\text { Yes } \\
\text { Issuance Date } \\
0.912\end{array}$ & $\begin{array}{c}308,762 \\
\text { Yes } \\
\text { Yes } \\
\text { Yes } \\
\text { Issuance Date } \\
0.936\end{array}$ \\
\hline
\end{tabular}




\section{Table 4 [Continued]}

Panel B. Measurement period of New Business Registration begins at Future Quarter

(1)

$\log (1+$ New Business Reg) Q+4 Log(1+New Business Reg) Q+5 Log(1+New Business Reg) Q+6 Sum(Q4+Q5+Q6)

\section{Post IPO}

\section{Observations}

Control

Year-Quarter FE

County F.E.

County Specific Y.Q.

Trend

Sample

Adjusted R-squared

$\begin{array}{cc}0.0972 * * & 0.0983 * * \\ (0.0420) & (0.0418) \\ 347,464 & 344,357 \\ \text { Yes } & \text { Yes } \\ \text { Yes } & \text { Yes } \\ \text { Yes } & \text { Yes } \\ & \\ \text { Yes } & \text { Yes }\end{array}$

Issuance Date

0.913
Issuance Date

$0.0986 * *$
$(0.0412)$
341,250
Yes
Yes
Yes
Yes

Issuance Date

0.913
$0.0780 *$

(0.0452)

341,250
Yes
Yes
Yes
Yes

Issuance Date

0.936

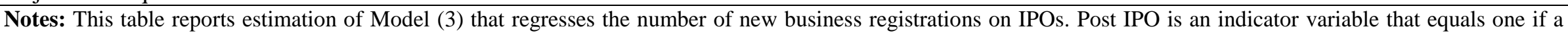

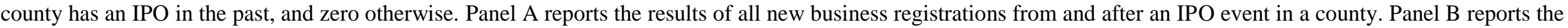

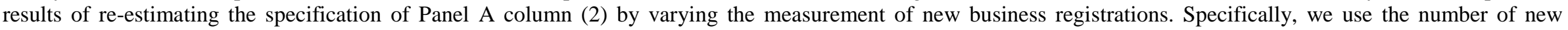

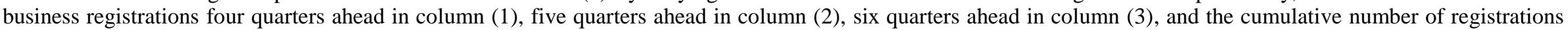

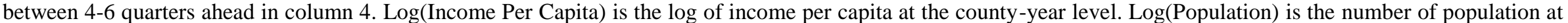

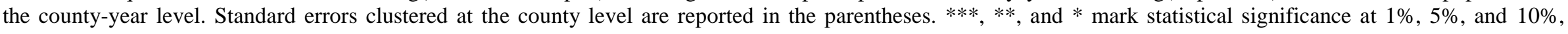
respectively. 
Table 5. IPOs and Entrepreneurial Interest at the County Level

\begin{tabular}{|c|c|c|}
\hline & $\begin{array}{c}(1) \\
\text { P(High Entr Search Share) }\end{array}$ & $\begin{array}{c}(2) \\
\mathrm{P}(\text { High Entr Search Share })\end{array}$ \\
\hline Post IPO & $\begin{array}{l}0.0156^{*} \\
(0.0082)\end{array}$ & $\begin{array}{l}0.0145^{*} \\
(0.0080)\end{array}$ \\
\hline Log(Population) & $\begin{array}{c}-0.0089 * * \\
(0.0042)\end{array}$ & $\begin{array}{c}-0.0093 * * \\
(0.0042)\end{array}$ \\
\hline Log(Income Per Capita) & $\begin{array}{c}-0.0466 * * \\
(0.0181)\end{array}$ & $\begin{array}{c}-0.0370 * * \\
(0.0166)\end{array}$ \\
\hline Log(Num Pub Firm in Area) & $\begin{array}{l}-0.0015 \\
(0.0064)\end{array}$ & $\begin{array}{l}-0.0006 \\
(0.0063)\end{array}$ \\
\hline Observations & 160,848 & 160,848 \\
\hline Year F.E. & Yes & Yes \\
\hline State F.E. & Yes & Yes \\
\hline State Year Trend & No & Yes \\
\hline Cluster & State & State \\
\hline Adjusted R-squared & 0.0731 & 0.0843 \\
\hline \multicolumn{3}{|c|}{$\begin{array}{l}\text { Notes: This table reports estimation of Model (3) as a linear probability model that regresses entrepreneurial search } \\
\text { intensity on IPOs. The outcome variable, High Entr Search Share, is an indicator variable that is defined as one in } \\
\text { the case that the DMA is in the top quartile of entrepreneurial search intensity in that quarter. We measure } \\
\text { entrepreneurial search intensity using internet searches for terms and phrases directly related to launching a business } \\
\text { as in (Barrios et al., 2020). Post IPO is an indicator variable that equals one if a county has an IPO in the past, and } \\
\text { zero otherwise. Log(Income Per Capita) is the log of income per capita at the county-year level. Log(Population) is } \\
\text { the number of population at the county-year level. Log(Num Pub Firm in Area) is the log number of public listed } \\
\text { firms in the state. Standard errors clustered at the state level are reported in the parentheses. ***, **, and * mark } \\
\text { statistical significance at } 1 \%, 5 \% \text {, and } 10 \% \text {, respectively. }\end{array}$} \\
\hline
\end{tabular}


Table 6. Spinoffs vs. Private to Public IPOs

(1)

Log $(1+$ New Business Reg $)$
(2)

$\log (1+$ New Business Reg $)$ $\begin{array}{ll}\text { Post Public IPO } & 0.1863^{*} \\ & (0.1068)\end{array}$

Post Private IPO

Observations

Control

Year-Quarter FE

County F.E.

Cluster
293,795

Yes

Yes

Yes

County
$0.2715^{* *}$

(0.1276)

298,128

Yes

Yes

Yes

County

Adjusted R-squared

0.858

0.863

Notes: This table reports estimation of Model (3) that regress new business registrations on two types of IPOs. Post Public IPO as an indicator variable that is set to one in county quarters after a subsidiary of an already public firm goes public. In contrast, Post Private IPO is defined based on the IPOs of private firms that go public. Control variables include $\log ($ Income Per Capita), the log of income per capita at the county-year level, and $\log$ (Population), the number of population at the county-year level. Standard errors clustered at the state level are reported in the parentheses. ***, **, and * mark statistical significance at $1 \%, 5 \%$, and $10 \%$, respectively. 
Table 7. IPOs, New Business Registrations, and Uncertainty

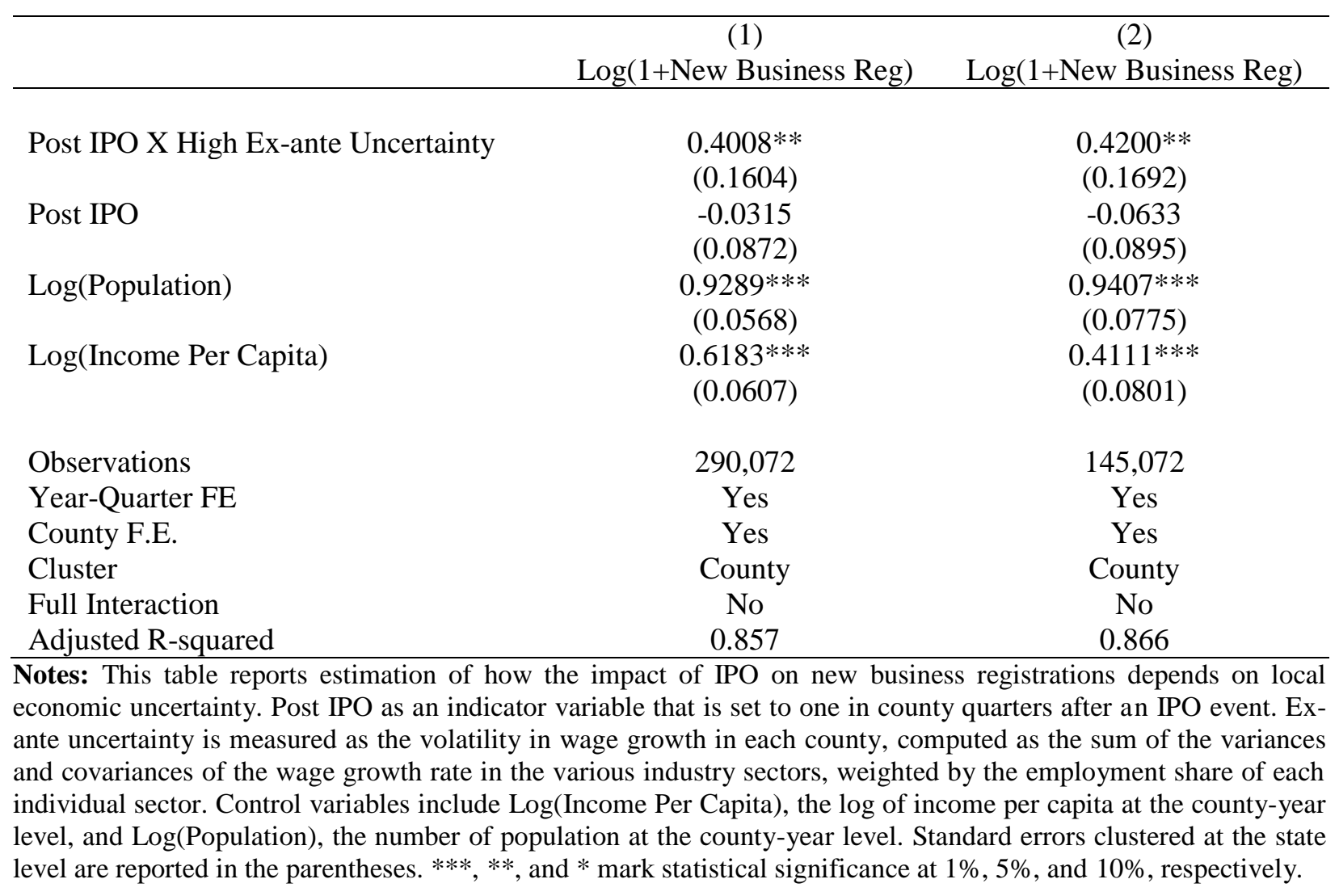


Table 8. Edgar Searches and New Business Registrations

Panel A. Edgar Downloads

(1)

$\log (1+$ Downloads $)$
(2)

$\log ($ Downloads $)$

\begin{tabular}{lcc} 
Post IPO & $0.2315^{*}$ & $0.2661^{* *}$ \\
& $(0.1303)$ & $(0.1334)$ \\
Observations & & \\
Year-Quarter FE & 136,656 & 117,384 \\
County FE & Yes & Yes \\
Adjusted R-squared & Yes & Yes \\
\hline
\end{tabular}

Panel B. Edgar Downloads and New Business Registration

(1)

$\log (1+$ New Business Reg $)$
(2)

$\log (1+$ New Business Reg $)$
$\log (1+$ Downloads $)$
$0.0093 * * *$
(0.0027)

$\log ($ Downloads $)$

$0.0089 * * *$

(0.0030)

\begin{tabular}{lcc} 
Observations & 136,656 & 117,384 \\
Year-Quarter FE & Yes & Yes \\
County FE & Yes & Yes \\
Adjusted R-squared & 0.910 & 0.904 \\
\hline
\end{tabular}

Notes: This table regresses the number of Edgar downloads on post IPOs and the number of new businesses on the number of Edgar downloads. In Panel A, the dependent variable is the log number of Edgar downloads at the county-year level. In Panel B, the dependent variable is the log number of new businesses at the county-year level. Post IPO as an indicator variable that is set to one in county quarters after an IPO event. Controls include log per capita income and log population at the county-year level. In both panels, the sample period is from 2007 to 2017. Standard errors clustered at the state level are reported in the parentheses. ***, **, and * mark statistical significance at $1 \%, 5 \%$, and $10 \%$, respectively. 
Table 9. Is This Just Economic Growth?

\begin{tabular}{lcccc}
\hline & $\begin{array}{c}(1) \\
\text { Avg Wage } \\
\text { Growth }\end{array}$ & $\begin{array}{c}(2) \\
\text { Avg Wage } \\
\text { Growth }\end{array}$ & $\begin{array}{c}(3) \\
\text { Avg Employment } \\
\text { Growth }\end{array}$ & $\begin{array}{c}(4) \\
\text { Avg Employment } \\
\text { Growth }\end{array}$ \\
\hline Post IPO & & & & -0.0013 \\
& -0.0007 & -0.0008 & 0.0002 & $(0.0014)$ \\
Observations & $(0.0008)$ & $(0.0014)$ & $(0.0013)$ & 210,702 \\
Control & 210,702 & 210,702 & 210,702 & Yes \\
Year F.E. & Yes & Yes & Yes & Yes \\
State F.E. & Yes & Yes & Yes & Yes \\
State Year & Yes & Yes & Yes & Yes \\
Trend & No & Yes & No & County \\
Cluster & County & County & County & 0.0547 \\
Adj. R-sq. & 0.406 & 0.400 & 0.0629 & \\
\hline
\end{tabular}

Notes: This table reports estimation of regressions of average wage growth and average employment growth on IPOs. Post IPO as an indicator variable that is set to one in county quarters after an IPO event. Control variables include Log(Income Per Capita), the log of income per capita at the county-year level, and Log(Population), the number of population at the county-year level. Standard errors clustered at the county level are reported in the parentheses. $* * *, * *$, and $*$ mark statistical significance at $1 \%, 5 \%$, and $10 \%$, respectively. 


\section{APPENDIX A VARIABLES DEFINITION}

\begin{tabular}{|c|c|c|}
\hline Name & Definition & Source \\
\hline Avg Wage Growth & Average wage growth in a county-year & Census \\
\hline Avg Employment Growth & Average employment growth in a county-year & Census \\
\hline High Ex-ante Uncertainty & $\begin{array}{l}\text { Volatility in wage growth in each county, computed as } \\
\text { the sum of the variances and covariances of the wage } \\
\text { growth rate in the various industry sectors, weighted by } \\
\text { the employment share of each sector }\end{array}$ & Census \\
\hline $\log (1+$ Download $)$ & Log of one plus the number of Edgar downloads. & EDGAR \\
\hline Log $(1+$ Establishment Birth $)$ & $\begin{array}{l}\text { Log of one plus the number Establishment Births. } \\
\text { Where Establishment Births are of establishments that } \\
\text { have zero employment in the first quarter of the initial } \\
\text { year and positive employment in the first quarter of the } \\
\text { subsequent year. }\end{array}$ & Census \\
\hline Log $(1+$ New Business Reg $)$ & $\begin{array}{l}\text { Log of one plus the number of new business } \\
\text { registrations }\end{array}$ & Startup Cartography \\
\hline Log $(1+$ New Business Reg) $Q+4$ & $\begin{array}{l}\text { Log of one plus the number of new business } \\
\text { registrations } 4 \text { quarters ahead }\end{array}$ & Startup Cartography \\
\hline Log $(1+$ New Business Reg $) Q+5$ & $\begin{array}{l}\text { Log of one plus the number of new business } \\
\text { registrations } 5 \text { quarters ahead }\end{array}$ & Startup Cartography \\
\hline Log $(1+$ New Business Reg) $Q+6$ & $\begin{array}{l}\text { Log of one plus the number of new business } \\
\text { registrations } 6 \text { quarters ahead }\end{array}$ & Startup Cartography \\
\hline Log(Num Pub Firm in Area) & $\begin{array}{l}\text { Log of the number of public listed firms in the area, } \\
\text { where area is either state or county }\end{array}$ & Compustat \\
\hline Log(Income Per Capita) & Log of income per capita in the area & Census \\
\hline Log(Population) & Log of total population in the area & Census \\
\hline Income Growth & Growth of income in the area & Census \\
\hline Pub Firm Presence Quintile & $\begin{array}{l}\text { Quintile of the number of public firms in an industry ( } 3 \\
\text { digit SIC) divided by the total number firms in the } \\
\text { industry }\end{array}$ & Census, Compustat \\
\hline Post IPO & $\begin{array}{l}\text { Indicator variable that is set to one in county quarters } \\
\text { after an IPO event }\end{array}$ & Thomson SDC \\
\hline Post Private IPO & $\begin{array}{l}\text { Indicator variable that is set to one in county quarters } \\
\text { after a private firm goes public }\end{array}$ & Thomson SDC \\
\hline Post Public IPO & $\begin{array}{l}\text { Indicator variable that is set to one in county quarters } \\
\text { after a subsidiaries of an already public firm goes public }\end{array}$ & Thomson SDC \\
\hline Population Growth & Population growth in the area & Census \\
\hline High Entr Search Share & $\begin{array}{l}\text { Indicator variable equal to one if entrepreneurial search } \\
\text { is in the top quartile. Entrepreneurial search includes: } \\
\text { "start a business," "start your own business," "start a } \\
\text { company," "how to incorporate," "entrepreneurship," } \\
\text { "become an entrepreneur," and "small business loan." }\end{array}$ & Google Search \\
\hline
\end{tabular}




\section{APPENDIX B CONCEPTUAL FRAMEWORK}

To improve our understanding of the potential interaction between information (specifically public firm disclosure) and entrepreneurial activities, we develop a simple conceptual framework. We build our framework by augmenting Luca (1978) 's managerial production function to include the quantity of information:

$$
F=f(a, I)
$$

where $a$ is the ability of the entrepreneur, and $I$ is the information available to the entrepreneur. Under our framework, an increase in information (a decrease in the cost of information

production) leads to higher entrepreneurial output for all entrepreneurs, higher profits. The additional information thus increases the incentives for individuals to create firms. We proceed to provide an analytical formulation of the relation between information and new firm formation through this viewpoint.

We begin with $\mathrm{N}$ potential entrepreneurs in the population with the choice of being either entrepreneurs or employees. Each individual has an ability level $a$ that is time-invariant. Ability is drawn from the distribution $G(a)$ with a continuous density $g(a)$ that is defined over the interval $S \subset \mathbb{R}_{+}$.

An entrepreneur's output is an outcome of the production function given their ability ( $a$ ) and the amount of information $(I)$ and can be defined as follows:

$$
F\left(a, I_{t}\right)=a^{\beta} I_{t}^{1-\beta}
$$

The parameter $\beta$ is bounded between zero and one. The acquisition of information is costly with a cost of $z_{t}$ that depends on the amount of information available via online, trade publications and other business news outlets as well as in the local community. The disclosure of public firms in their filings, the media coverage of the firms as well as analysts foster the diffusion of all the information that entrepreneurs may need, thus decreasing the cost of acquiring the information and increasing the total quantity of information available.

Given an ability level for the entrepreneur and the quantity of information, a firm produces output $y\left(a, I_{t}\right)$ according to the following specification:

$$
y_{t}\left(a, I_{t}\right)=\lambda_{t}\left(a^{\beta} I^{1-\beta}\right)^{1-\theta} H_{t}^{\theta} .
$$


The terms in the first bracket is the entrepreneurial production function, and the second term is the traditional production function with an entrepreneur as another input. For simplicity, we can think of $H$ as labor (the number of employees) paid a wage of $w_{t} . \lambda_{t}$ is a technology factor. As can be seen from the production function, we model the output as a function of the information gathered by the entrepreneur in addition to the individual's ability. Thus, the choice to become an entrepreneur directly depends on the cost of information in the economy and therefore the amount of public disclosure.

We can now solve for the number of entrepreneurs, which is determined at the margin when the profit earned as an entrepreneur is equal to their outside option as a full-time worker. We can define a threshold of ability $\overline{a_{t}}$ as the level of ability that an individual is indifferent between entrepreneurship and becoming an employee:

$$
\pi\left(\overline{a_{t}}, z_{t}\right)=w_{t}
$$

From this equation it is clear that individuals with abilities higher than $\overline{a_{t}}$ become entrepreneurs whereas those with lower ability choose to be employees. For simplicity, we normalize the output price to one, and we have input prices as relative prices. Thus, the potential entrepreneur will maximize profits such that

$$
\pi(a)=\max _{H_{t}, I_{t}}\left\{\lambda_{t}\left(a^{\beta} I^{1-\beta}\right)^{1-\theta} H_{t}^{\theta}-z_{t} I_{t}-w_{t} H_{t}\right\}
$$

Taking the first-order conditions provides us with the mix of labor and information adopted by an entrepreneur of ability $a$, such that

$$
\frac{H_{t}}{I_{t}}=\frac{\theta z_{t}}{(1-\theta)(1-\beta) w_{t}}
$$

It is important to note that this ratio does not depend on an individual's ability but rather on the relative prices of labor and information in a similar manner to Lucas (1978). As a result, each period, the entrepreneur will use the same mix of inputs, and we can derive the entrepreneur's demand for each of the factors: 


$$
\begin{gathered}
I_{t}(a)=a \lambda_{t}^{\frac{1}{\beta(1-\theta)}} \Delta_{t} \\
H_{t}(a)=a \lambda_{t}^{\frac{1}{\beta(1-\theta)}} \Delta_{t} \frac{\theta}{w} \frac{z}{(1-\theta)(1-\beta)},
\end{gathered}
$$

Where $\Delta_{t}=\left[\frac{z}{(1-\theta)(1-\beta)}\right]^{-1 / \beta}\left[\frac{w}{\theta}\right]^{\frac{\theta}{\beta(\theta-1)}}$.

From equation 5, we see that $\frac{\partial I(a)}{\partial z_{t}}<0$, thus the higher the cost of obtaining the information the lower the use of information by the entrepreneur. We can now derive the equilibrium levels of output and profit for an entrepreneur with ability level $a$ :

$$
\begin{aligned}
y_{t}\left(a, z_{t}\right) & =a \lambda_{t}^{\frac{1}{\beta(1-\theta)}}\left(\Delta_{t}\right)^{1-\beta+\beta \theta}\left(\frac{\theta}{w} \frac{z_{t}}{(1-\beta)(1-\theta)}\right)^{\theta} \\
\pi\left(a, z_{t}\right) & =\left[1-\lambda_{t}\left((1-\beta)(1-\theta)+\frac{\theta}{w}\right)\right] y_{t}\left(a, z_{t}\right)
\end{aligned}
$$

Each individual's decision to enter entrepreneurship is a function of their ability $(a)$. Given that profit is an increasing function of ability, at each period, all individuals with ability levels above $\overline{a_{t}}$ decide to become entrepreneurs while those below the threshold go to full-time employment. Combining Equations (7) and (8) into Equation (2), we can obtain the value of $\overline{a_{t}}$ :

$$
\overline{a_{t}}=\frac{w_{t}}{\left[1-\lambda_{t}\left((1-\beta)(1-\theta)+\frac{\theta}{w}\right)\right]}\left[\lambda_{t}\right]^{-\frac{1}{\beta(1-\theta)}}\left(\frac{z_{t}}{(1-\beta)(1-\theta)}\right)^{\frac{1}{\beta}}-1\left(\frac{w}{\theta}\right)^{\frac{\theta}{\beta(1-\theta)}}
$$

It is clear from Equation (9) that $\frac{\partial \overline{a_{t}}}{\partial z_{t}} \geq 0$, when $w_{t} \geq \frac{\lambda \theta}{1-\lambda(1-\beta)(1-\theta)}$ and $\lambda \geq \frac{1}{(1-\beta)(1-\theta)}$. We assume a partial equilibrium model, indicating that $w_{t}$ and $z_{t}$ are given. In essence, as long as the full-time employment wage is high enough, $\overline{a_{t}}$ is increasing in $z_{t}$ the information cost. Thus, public firm disclosures or equivalently an increase in the volume of information, reduces the cost of information, raises firms' profit, and, therefore, entrepreneurial returns. This induces additional wage earners and lower ability entrepreneurs to become entrepreneurs and, in turn, increases new business formation. 


\section{APPENDIX TABLES}

In this section, we show that moving from the bottom quintile of public firm presence in an industry to the top quintile is associated with a $12 \%$ increase in the number of establishments with 0 to 5 employees in that industry-year (Table A1). Consistent with public information being more useful for entrepreneurs in their decision to start the new firm, we find that the relationship between public firm presence and the number of establishments is larger for these small firms as compared to medium, large or extra-large establishments (Table A2). We estimate that the relationship between establishment growth and public firm presence is more than $40 \%$ greater for small firms than for larger firms.

Table A1. Public Firm Presence and Small Establishments

\begin{tabular}{lccc}
\hline & $\begin{array}{c}(1) \\
\text { Log (Small } \\
\text { Establishment) }\end{array}$ & $\begin{array}{c}\text { Log (Small } \\
\text { Establishment) }\end{array}$ & $\begin{array}{c}(3) \\
\text { Log (Small } \\
\text { Establishment) }\end{array}$ \\
\hline Pub Firm Presence Quintile & & & \\
& $0.0340^{* * *}$ & $0.0333^{* * *}$ & $0.0271^{* * *}$ \\
Log(Income Per Capita) & $(0.0076)$ & $(0.0076)$ & $(0.0076)$ \\
& 0.0456 & & 0.0449 \\
Log(Population) & $(0.0402)$ & & $(0.0402)$ \\
& $0.7569^{* * *}$ & & $0.7584^{* * *}$ \\
Observations & $(0.0977)$ & & $(0.0977)$ \\
Control & & 790,606 & 790,606 \\
Year F.E. & 790,606 & Yes & Yes \\
MSA FE & Yes & Yes & Yes \\
NAICS3 & Yes & Yes & Yes \\
Year X MSA FE & Yes & Yes & Nes \\
NAICS3 Year Trend & Yes & Yes & Yes \\
Adjusted R-squared & No & No & 0.856 \\
\hline
\end{tabular}




\section{APPENDIX TABLES [Continued]}

Table A2. Public Firm Presence by Establishment Size

\begin{tabular}{lccc}
\hline & $\begin{array}{c}(1) \\
\text { Log (Num } \\
\text { Establishment) }\end{array}$ & $\begin{array}{c}(2) \\
\text { Log (Num } \\
\text { Establishment) }\end{array}$ & $\begin{array}{c}(3) \\
\text { Log (Num } \\
\text { Establishment) }\end{array}$ \\
\hline I(Small Firm) X Pub Firm & & & \\
Presence Quintile & $0.4296^{* * *}$ & $0.6318^{* * *}$ & $0.6230^{* * *}$ \\
Pub Firm Presence Quintile & $(0.0173)$ & $(0.0328)$ & $(0.0418)$ \\
& $-0.2106^{* * *}$ & $-0.2997^{* * *}$ & $-0.3090^{* * *}$ \\
Observations & $(0.0284)$ & $(0.0313)$ & $(0.0340)$ \\
Control & & & $1,581,212$ \\
Year X MSA FE & $1,581,212$ & $1,581,212$ & Yes \\
NAICS3 & Yes & Yes & Yes \\
NAICS3 Year Trend & Yes & Yes & Yes \\
Comparison Group & Yes & Yes & Yes \\
Mean of Outcome & Yes & Yes & Xlarge \\
Adjusted R-squared & Med & Large & 1.622 \\
Not This & 1.867 & 1.695 & 0.637 \\
\hline
\end{tabular}

Note: This table reports the estimation of regressions of the number of small establishments (Panel A) and the total number of establishments (Panel B) on public firm presence. Pub Firm Presence Quintile is the quintile rank of public firm presence taken from Shroff et al. (2017) and Roychowdhury et al. (2019), defined as and the number of public firms in an industry ( 3 digit SIC) divided by the total number firms in the industry, both public and private. In Panel B, I(Small Firm) is an indicator variable that equals one if the establishment has 0-5 employees, and zero otherwise. Control variables include $\log$ (Income Per Capita), the log of income per capita at the county-year level, and $\log ($ Population), the number of population at the county-year level. Standard errors clustered at the county level are reported in the parentheses. $* * *, *$, and $*$ mark statistical significance at $1 \%, 5 \%$, and $10 \%$, respectively. 